\title{
PENGARUH KUALITAS PELAYANAN TERHADAP KEPUASAN PELANGGAN PADA KANTOR PELAYANAN KEKAYAAN NEGARA DAN LELANG (KPKNL) PALU
}

\author{
Ni Nyoman Suriani \\ Idris Azis \\ Moh. Ali Murad \\ Manajemen, Fakultas Ekonomi, Universitas Tadulako \\ E-mail: ninyomansuriani63@gmail.com.
}

\begin{abstract}
The purposes of this research are: (1) to determine the influence of physical evidence, reliability, responsiveness, assurance, and empathy on customers' satisfaction in the Office of State Property and Auction (KPKNL) Palu, (2) to determine the influence of physical evidence on customers' satisfaction in the KPKNL of Palu (3) to determine the influence of reliability on customers' satisfaction in the $K P K N L$ of Palu, (4) to determine the influence of responsiveness on customers' satisfaction in the $K P K N L$ of Palu (5) to determine the influence of assurance on customers' satisfaction in the KPKNL Palu, (6) to determine the influence of empathy on customer satisfaction in the KPKNL Palu. By using associative research approach, this study examines a sample of 39 customers. Data analysis technique used is multiple linear regressions. The results of hypothesis testing can be concluded that: (1) physical evidence, reliability, responsiveness, assurance, and empathy simultaneously have significant influence on customer satisfaction; (2) partially, physical evidence variable, reliability and responsiveness have non- significant influence on customer satisfaction; (3) assurance and empathy partially have significant influence on customer satisfaction.
\end{abstract}

Keywords: service quality, customer satisfaction

\begin{abstract}
ABSTRAK
Penelitian ini bertujuan untuk mengetahui: (1) Untuk mengetahui bukti fisik, kehandalan, daya tanggap, jaminan dan empati berpengaruh simultan terhadap kepuasan pelanggan pada Kantor Pelayanan Kekayaan Negara dan Lelang (KPKNL) Palu; (2) Untuk mengetahui bukti fisik berpengaruh secara parsial terhadap kepuasan pelanggan pada Kantor Pelayanan Kekayaan Negara dan Lelang (KPKNL) Palu; (3) Untuk mengetahui kehandalan berpengaruh secara parsial terhadap kepuasan pelanggan pada Kantor Pelayanan Kekayaan Negara dan Lelang (KPKNL) Palu, (4) Untuk mengetahui daya tanggap berpengaruh secara parsial terhadap kepuasan pelanggan pada Kantor Pelayanan Kekayaan Negara dan Lelang (KPKNL) Palu, (5) Untuk mengetahui jaminan berpengaruh secara parsial terhadap kepuasan pelanggan pada Kantor Pelayanan Kekayaan Negara dan Lelang (KPKNL) Palu, (6) Untuk mengetahui empati berpengaruh secara parsial terhadap kepuasan pelanggan pada Kantor Pelayanan Kekayaan Negara dan Lelang (KPKNL) Palu. Penelitian ini menggunakan dasar penelitian asosiatif. Pada penelitian asosiatif ini minimal terdapat dua variabel yang dihubungkan. Jadi penelitian asosiatif ini merupakan penelitian yang meneliti tentang hubungan antara dua variabel atau lebih dengan sampel 39 pelanggan. Teknik analisis data yang digunakan adalah regresi linear berganda. Hasil analisis dan pengujian hipotesis dapat disimpulkan bahwa: (1) berdasarkan hasil uji regresi diperoleh sig. F sebesar 0,001 <0,05, yang dapat diartikan bahwa variabel bukti fisik, kehandalan, daya tanggap, jaminan dan empati berpengaruh secara simultan terhadap kepuasan pelanggan; (2) berdasarkan uji regresi diperoleh variabel bukti fisik, kehandalan dan daya tanggap secara parsial ada pengaruh tapi tidak signifikan terhadap kepuasan pelanggan; (3) berdasarkan uji regresi diperoleh variabel jaminan dan empati secara parsial berpengaruh signifikan terhadap kepuasan pelanggan.
\end{abstract}

Kata kunci: kualitas pelayanan, kepuasan pelanggan 


\section{PENDAHULUAN}

Dewasa ini, perusahaan atau organisasi perlu melakukan pengelolaan dan pengembangan aset yang dimiliki untuk mendukung kelangsungan hidup perusahaan. Aset yang dimiliki perusahaan salah satunya yaitu sumber daya manusia yang berperan penting dalam proses operasional perusahaan. Demi menjaga kelangsungan perusahaan dan memenangkan persaingan bisnis yang sangat kompetitif, suatu perusahaan membutuhkan strategi yang tepat.

Salah satu fungsi manajemen sumber daya manusia dalam Sunyoto (2015:7) yaitu fungsi perencanaan merupakan fungsi manajemen sumber daya manusia yang dinilai esensial, karena menyangkut rencana pengelolaan sumber daya manusia organisasi baik dalam jangka pendek maupun jangka panjang di mana hal tersebut berkaitan erat dengan opersionalisasi organisasi dan kelancaran kerja yang ada di dalamnya. Hal ini diharapkan akan meningkatkan kinerja pegawai yang mendorong terciptanya kualitas pelayanan dalam upaya pencapaian tujuan perusahaan terkhusus pada kepuasan pelanggan.

Berdasarkan salah satu pengertian kepuasan pelanggan konsep dasar riset pemasaran dan perilaku konsumen dalam Sunyoto (2012:226) yaitu kepuasan pelanggan adalah tingkat perasaan seseorang setelah membandingkan (kinerja atau hasil) yang dirasakan dibandingkan dengan harapannya. Jadi tingkat kepuasan adalah fungsi dari perbedaan antara kinerja yang dirasakan dengan harapan. Pelanggan bisa mengalami salah satu dari tiga tingkat kepuasan umum yaitu kalau kinerja sesuai dengan harapan pelanggan akan merasa puas dan bila kinerja bisa melebihi harapan maka pelanggan akan merasakan sangat puas senang atau gembira (Philip Kotler, 1997). Kepuasan pelanggan merupakan faktor penting dan hal yang tidak mudah untuk mewujudkannya dalam suatu bisnis. Dalam rangka memberikan kepuasan kepada konsumen perusahaan perlu memperhatikan kualitas pelayanan yang ditunjukkan kepada pelanggan.

Observasi dilakukan pada Kantor Pelayanan Kekayaan Negara dan Lelang Palu. KPKNL Palu merupakan unit organisasi yang diberi mandat oleh Kantor Pusat Direktorat Jendral Kekayaan Negara (DJKN) untuk mengelola kekayaan Negara secara maksimal untuk membenahi manajemen asset Negara menuju terlaksananya tertib administrasi, tertib hukum dan tertib fisik sehingga terwujud pengelolaan kekayaan Negara yang optimal satuan kerja-satuan kerja (SatKer) yang berada di wilayah tersebut. Selain mengelola kekayaan Negara, KPKNL Palu juga melaksanakan pengurusan piutang Negara perbankan dan non perbankan serta memeberikan pelayanan lelang eksekusi dan non eksekusi. KPKNL Palu berada dalam wilayah kerja Kanwil XVI DJKN Manado yang terdiri dari Kota Palu, Kabupaten Donggala, Kabupaten Sigi Biromaru, Kabupaten Parigi Moutong, Kabupaten Poso, Kabupaten Tojo Una una, Kabupaten Morowali, Kabupaten Banggai, Kabupaten Banggai Kepulauan, Kabupaten Toli-toli, dan Kabupaten Buol.

Berdasarkan hasil wawancara dengan salah satu pelanggan KPKNL Palu atas nama bapak Irwan Sainong menyatakan bahwa keluhan terhadap pelayanan Kantor Pelayanan Kekayaan Negara dan Lelang (KPKNL) Palu, baik dari pelanggan maupun calon pelanggannya yang menyebabkan pelanggan menjadi kurang puas, antara lain dimana pihak Kantor Pelayanan Kekayaan Negara dan Lelang (KPKNL) Palu kurang adil dalam melakukan pelayanan, serta kecepatan penanganan keluhan yang kurang efektif sehingga membutuhkan waktu lebih dari yang diharapkan oleh pelanggan. Penanganan keluhan memberikan peluang untuk mengubah seorang pelanggan tidak puas menjadi pelanggan yang puas. Proses penanganan keluhan yang efektif mulai idetifikasi disertai dengan penentuan yang menyebabkan pelanggan tidak puas dan mengeluh.

Menurut Tjiptono (1997:138) paling tidak ada 4 aspek untuk menangani keluhan, yaitu (1) empati terhadap pelanggan yang marah, (2) kecepatan dalam penanganan keluhan, (3) kewajaran atau keadilan dalam memecahkan permasalahan atau keluhan, (4) kemudahan bagi konsumen untuk menghubungi perusahaan. 
Melalui observasi yang dilakukan pada Kantor Pelayanan Kekayaan Negara dan Lelang (KPKNL) Palu, dengan mewawancarai bapak Fikri Hudori sebagai Kepala Sub Bagian Umum menyatakan bahwa kualitas pelayanan yang diukur dengan dimensi bukti fisik, kehandalan, daya tanggap, jaminan, dan empati masih belum mampu memberikan pelayanan yang maksimal terhadap pelanggannya. Dimana lingkungan pekerjaan yang ada masih kurang memberikan kenyamanan dalam melakukan transaksi, sehingga ruang gerak pagawai dalam melayani pelanggan yang bertransaksi lelang kurang memadai. Beliau menjelaskan bahwa masih kurangnya pengetahuan pegawai dikarenakan adanya perpindahan kerja dari devisi satu ke devisi yang lain. Serta ditunjukkanya dengan ketidakmampuan pegawai menjaga kepercayaan pelanggan ketika pemilik asset melunasi asetnya yang bermasalah. Kualitas pelayanan mempunyai pengaruh signifikan terhadap kepuasan pelanggan yang sesuai dengan penelitian yang dilakukan oleh Aryani dan Rosinta (2010).

Meningkatnya kualitas pelayanan akan berdampak pada kepuasan pelanggan yang sesuai dengan penelitian Sonya (2010) menunjukkan kualitas pelayanan berpengaruh positif terhadap kepuasan pelanggan. Menurut Kotler dalam Syachrul (2010) kepuasan pelanggan adalah perasaan senang atau kecewa seseorang yang muncul setelah membandingkan antara persepsi atau kesan terhadap kinerja atau hasil suatu produk dan harapan-harapannya. Berdasarkan hasil wawancara dengan salah satu pelanggan KPKNL Palu atas nama bapak Irwan Sainong menyatakan bahwa ketidakpuasan terhadap tingkat kinerja pegawai KPKNL Palu karena disebabkan pengalaman buruk yang muncul akibat kurangnya jaminan atas barang yang dilelang.

Berdasarkan latar belakang masalah yang telah diuraikan, maka permasalahan penelitian ini adalah apakah bukti fisik, kehandalan, daya tanggap, jaminan dan empati berpengaruh simultan dan parsial terhadap kepuasan pelanggan pada Kantor Pelayanan Kekayaan Negara dan Lelang (KPKNL) Palu?

\section{KAJIAN LITERATUR DAN PENGEMBANGAN HIPOTESIS Pengertian Kualitas Pelayanan}

Konsep kualitas pada dasarnya merupakan ukuran yang sangat relatif terhadap kebaikan suatu produk atau jasa yang terdiri dari kualitas desain dan kualitas kesesuaian. Kualitas desain merupakan fungsi spesifikasi produk, sedangkan kualitas kesesuaian adalah suatu ukuran seberapa jauh produk mampu memenuhi kualitas yang diharapkan.

Zeitnal et.al dalam Laksana (2008:88) mendefinisikan kualitas pelayanan sebagai "The extent of between customers expectations or desire and their perceptions". Dari pernyataan tersebut dikemukakan bahwa kualitas pelayanan yang diterima konsumen dinyatakan besarnya perbedaan antara kualitas adalah "Quality is degree of excellent intended, and the control of variability in achieving that excellent, in meeting the customers requirements". Dikatakan bahwa kualias adalah tingkat mutu yang diharapkan, dan pengendalian keragaman dalam mencapai mutu tersebut untuk memenuhi kebutuhan konsumen. Untuk dapat memberikan kualitas pelayanan yang baik maka perlu dibina hubungan yang erat antar perusahaan, dalam hal ini adalah pegawai dengan pemakai jasa tersebut.

Menurut Kotler (2009:42) kualitas layanan adalah besarnya perbedaan antara harapan konsumen dengan persepsi konsumen. Definisi American Society For Quality dalam Kotler dan Keller (2009:143) kualitas adalah totalitas fitus dan karakteristik produk pada kemampuannya untuk memuaskan kebutuhan yang dinyatakan atau tersirat.

Berdasarkan uraian yang dikemukakan, maka dapat disimpulkan kualitas pelayanan berpusat pada upaya pemenuhan kebutuhan dan keinginan pelanggan serta ketepatan penyampainnya untuk mengimbangi harapan pelanggan atau masyarakat. Kualitas layanan ditentukan oleh keamampuan pegawai dalam memnuhi kebutuhan dan keinginan pelanggan sesuai dengan ekspektasi pelanggan. Masyarakatlah yang mengkonsumsi dan merasakan layanan yang diberikan, sehinggan merekalah 


\section{Suriani, N.N.}

yang mengkonsumsi dan merasakan layanan yang diberikan, sehingga merekalah yang seharusnya menilai dan menentukan kualitas pelayanan.

\section{Dimensi Kualitas Pelayanan}

Kualitas jasa fokusnya pada upaya pemenuhan kebutuhan dan keinginan pelanggan serta ketepatan penyampaian untuk mengimbangi harapan pelanggan. Tjiptono dan Diana dalam Haryanto (2013), kualitas jasa adalah tingkat keunggulan yang diharapkan dan pengendalian atas tingkat keunggulan tersebut untuk memenuhi keinginan pelanggan.

Perkembangan selanjutnya pada tahun 1988, Parasuraman dalam Haryanto (2013) menyatakan bahwa sepuluh dimensi yang ada dapat dirangkum menjadi hanya lima dimensi pokok yaitu:

1. Bukti fisik (Tangible) yaitu peralatan modern, fasilitas yang tampak menarik secara visual, pegawai yang memiliki penampilan rapi dan professional, dan bahkan yang berhubungan dengan jasa mempunyai daya tarik.

2. Kehandalan (Reliability) yaitu menyediakan jasa sesuai yang dijanjikan, keandalan dalam penanganan masalah layanan pelanggan, melaksanakan jasa dengan benar pada saat pertama, menyediakan jasa pada waktu yang dijanjikan mempertahankan catatan bebas kesalahan, dan pegawai yang mempunyai pengetahuan untuk menjawab pertanyaan pelanggan.

3. Daya Tanggap (Responsiveness) yaitu selain memberitahu pelanggan tentang kapan layanan akan dilaksanakan, layanan tepat waktu bagi pelanggan, kesediaan untuk membantu pelanggan merasa aman dalam transaksi mereka, dan pegawai yang selalu sopan.

4. Jaminan (Assurance) yaitu pegawai yang menanamkan keyakinan pada pelanggan, membuat pelanggan merasa aman dalam transaksi mereka, dan pegawai yang selalu sopan.

5. Empati (Emphaty) yaitu memberikan perhatian pribadi kepada pelanggan, pegawai yang menghadapi pelanggan dengan cara yang penuh perhatian, mengutamakan kepentingan terbaik pelanggan, pegawai yang memahami kebutuhan pelanggan mereka dan jam bisnis yang nyaman.

\section{Pengertian Kepuasan Pelanggan}

Kotler dan Keller dalam Syachrul (2010) menjelaskan kepuasan pelanggan adalah perasaan senang atau kekecewaan seseorang setelah membandingkan kinerja atau hasil yang dirasakan dibandingkan dengan harapannya, sedangkan Buttle dalam Adam (2010:98) mendefinisikan "customer satisfaction is customer's fulfillment response to a consumption experience, or some part of it. Customer satisfaction is a pleasurable fulfillment response, dissatisfaction is a unpleasurable fulfillment response". Maksudnya, kepuasan pelanggan merupakan tanggapan atas pemenuhan pelanggan terhadap sebuah pengalaman konsumsi, atau sebagai kecil dari pengalaman itu.

Kotler dan Keller (2009:139) mendefinisikan kepuasan (satisfaction) sebagai perasaan senang atau kecewa seseorang yang timbul karena membandingkan kinerja yang dipersepsikan produk (atau hasil) terhadap ekspektasi mereka. Jika kineja gagal memenuhi ekspektasi, pelanggan akan tidak puas. Jika kinerja sesuai dengan ekspektasi, pelanggan akan puas. Jika kinerja melebihi ekspektasi, pelanggan akan sangat puas atau senang. Penilaian pelanggan atas kinerja produk tergantung pada banyak faktor, terutama jenis hubungn loyalitas yang dimiliki pelanggan dengan sebuah merek. Konsumen sering membentuk persepsi yang lebih menyenangkan tentang sebuah produk dengan merek yng sudah mereka anggap positif.

\section{Dimensi Kepuasan Pelanggan}

Menurut Kotler dalam Syachrul (2010) kepuasan pelanggan sebagai perasaan senang atau kecewa seseorang yang muncul setelah membandingkan antara persepsi atau kesan terhadap kinerja atau hasil suatu produk dan harapan-harapannya. Jadi, kepuasan merupakan fungsi dari persepsi atau kesan atas kinerja dan harapan. Jika kinerja berada dibawah harapan maka pelanggan tidak puas. Jika kinerja memenuhi harapan maka pelanggan akan puas. Jika kinerja memenuhi harapan maka pelanggan akan 
amat puas atau senang. Dalam penelitian ini variabel kepuasan pelanggan menggunakan teori Kotler dalam Syachrul (2010) yaitu:

1. Tingkat Harapan yaitu mengukur besarnya harapan yang muncul atas pelayanan yang diberikan kepada pelanggan pada Kantor Pelayanan Kekayaan Negara dan Lelang (KPKNL) Palu.

2. Tingkat Kinerja adalah mengukur besarnya pengalaman yang muncul atas pelayanan yang diberikan kepada pelanggan pada Kantor Pelayanan Kekayaan Negara dan Lelang (KPKNL) Palu.

3. Kepuasan yang dirasakan pelanggan merupakan perasaan seseorang pelanggan sebagai respon atau reaksi atas pelayanan atau kinerja yang diterimanya, dimana hal tersebut dapat diukur dengan membandingkan antara harapan pelanggan atas pelayanan pada Kantor Pelayanan Kekayaan Negara dan Lelang (KPKNL) Palu.

4. Pelayanan adalah suatu kegiatan yang dilaksanakan dengan tujuan untuk memberi kepuasan kepada pelanggan dalam melakukan pelayanan terutama dibidang jasa Kantor Pelayanan Kekayaan Negara dan Lelang (KPKNL) Palu.

\section{Harapan Pelanggan}

Jika para pemasar meningkatkan harapan terlalu tinggi, para pemebeli cenderung akan kecewa. Sebaliknya, jika perusahaan menetapkan harapan terlalu rendah, maka para pembeli tidak tertarik (walaupun mereka yang benar-benar membeli akan terpuaskan). Contoh, menjamin "kepuasan total" dan akan mengganti atas biaya perusahaan terhadap setiap peralatan milik pelanggan yang tidak puas selama periode tiga tahun setelah pemebelian (Kotler, 2009:134).

\section{Hubungan antar Kualitas Pelayanan dan Kepuasan Pelanggan}

Pelayanan perusahaan yang ditunjukkan kepada pelanggan merupakan elemen yang sangat penting agar dapat menjamin kelangsungan hidup atau menjaga kestabilan usaha perusahaan, karena perusahaan sangat mengharapkan kepuasan dari pelanggan, seperti yang dikemukakan Tjiptono dalam Haryanto (2013).

Kualitas memiliki hubungan yang erat dengan kepuasan pelanggan, kualitas memberikan sesuatu dorongan kepada pelanggan untuk menjalin ikatan hubungan yang kuat dengan perusahaan. Dalam jangka panjang ikatan seperti ini memungkinkan perusahaan untuk memahami dengan seksama harapan pelanggan serta kebutuhan pelanggan. Dengan demikian perusahaan dapat meningkatkan kepuasan pelanggan dimana perusahaan meminimumkan pengalaman pelanggan yang kurang menyenangkan.

Kepuasan pelanggan sangat menentukan ketahanan perusahaan dalam menghadapi persaingan. Setiap perusahaan yang ingin tetap bertahan di tengah ketatnya persaingan dunia industri perusahaan harus mempunyai kelebihan-kelebihan yang membuatnya unggul dibanding dengan perusahaanperusahaan lain yang dimana kelebihan tersebut akan menciptakan kepuasan pelanggan. Salah satu cara menempatkan sebuah perusahaan agar lebih unggul dibandingkan dengan perusahaan lain adalah dengan memberikan pelayanan yang berkualitas kepada pelanggan. Zeithaml dalam Riqkqy et.al (2016) berpendapat bahwa kualitas pelayanan adalah penyampaian jasa yang baik atau sangat baik jika dibandingkan dengan ekspektasi pelanggan. Ekspektasi pelanggan terbentuk dari pengalaman masa lalu, perkataan, dan iklan. Dapat disimpulkan apabila perusahaan dapat memberikan pelayanan yang berkualitas sesuai dengan harapan maupun tuntutan para pelanggan, maka pelanggan merasakan kepuasan tersendiri.

\section{Kerangka Pemikiran}

Menciptakan kepuasan pelanggan, perusahaan harus dapat menigkatkan kualitas pelayanannya (service quality), kepuasan pelanggan dapat diciptakan melalui kualitas pelayanan yang diberikan oleh perusahaan kepada para pelanggannya. Semakin baik kualitas pelayanannya, akan semakin tinggi pula kepuasan pelanggan terhadap perusahaan tersebut. 
Berkaitan dengan hal itu, maka peneliti tertarik mengkaji apakah kualitas pelayanan telah diberikan sesuai dengan harapan pelanggan dan berpengaruh terhadap kepuasan pelanggan KPKNL Palu. Kualitas pelayanan diukur dengan menggunakan lima dimensi yang terdiri dari Tangible (Bukti Fisik), Reliability (Kehandalan), Responsiveness (Daya Tanggap), Assurance (Jaminan), dan Emphaty (Empati).

Kerangka pemikiran dalam penelitian ini adalah bagaimana kualitas pelayanan dapat mempengaruhi kepuasan pelanggan Pada Kantor Pelayanan Kekayaan Negara dan Lelang (KPKNL) Palu. Variabel bebas dalam penelitian ini adalah Kualitas Pelayanan (X) yang terdiri dari bukti fisik $\left(\mathrm{X}_{1}\right)$, kehandalan $\left(\mathrm{X}_{2}\right)$, daya tanggap $\left(\mathrm{X}_{3}\right)$, jaminan $\left(\mathrm{X}_{4}\right)$, dan empati $\left(\mathrm{X}_{5}\right)$, sedangkan variabel terikat adalah Kepuasan pelanggan (Y), sebagaimana digambarkan dalam kerangka pemikiran sebagai berikut.

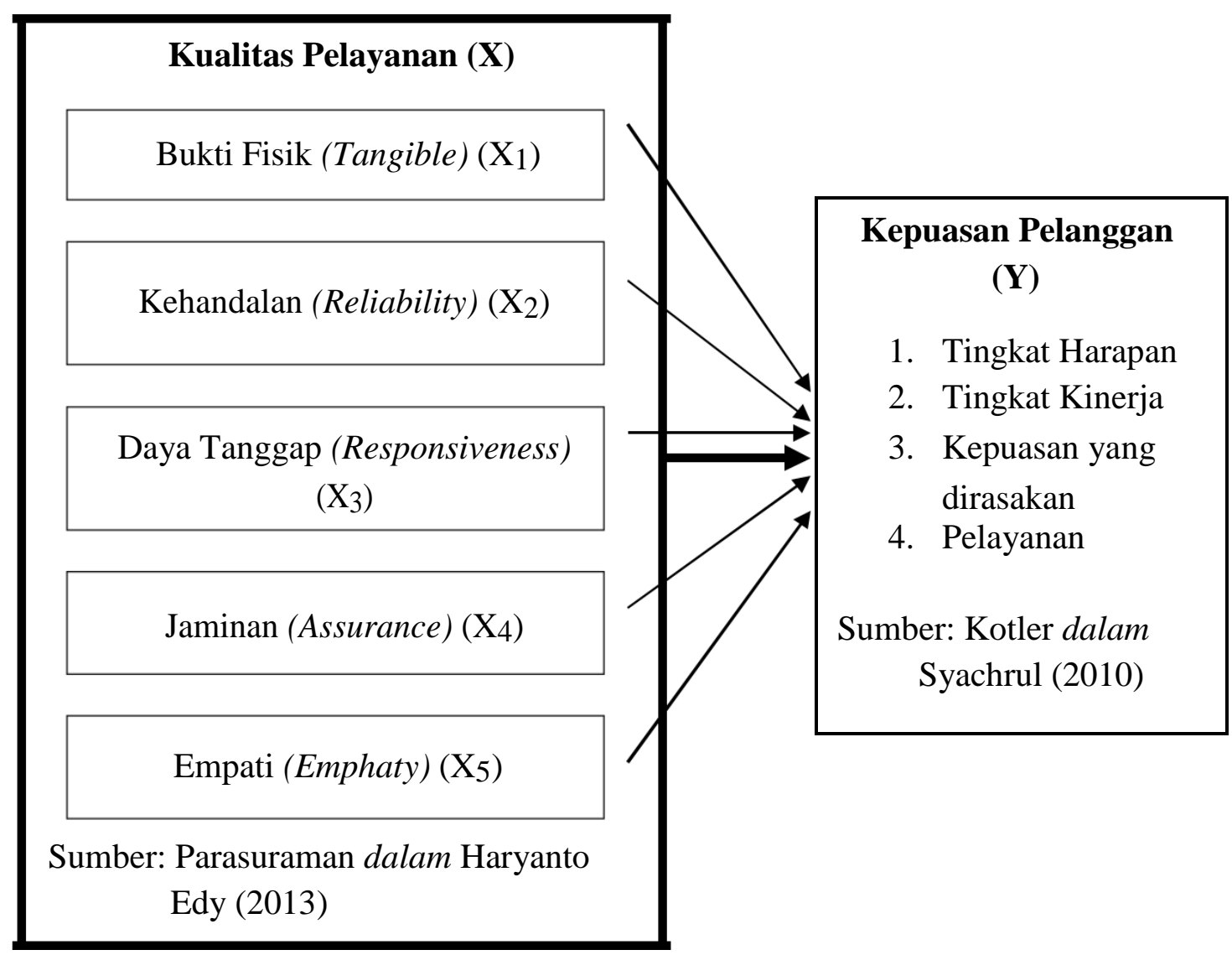

\section{Gambar 1 Kerangka Pemikiran Penelitian}

\section{Keterangan:}

$\longrightarrow$ : Pengaruh secara simultan (pengaruh serempak variabel bebas)

$\longrightarrow$ : Pengaruh secara Parsial (pengaruh masing-masing variabel bebas)

\section{Hipotesis}

Berdasarkan pada rumusan masalah dan kerangka pikir diatas, maka dalam penelitian ini dikemukakan hipotesis sebagai kerangka acuan sebagai berikut:

1. Bukti fisik, kehandalan, daya tanggap, jaminan dan empati berpengaruh simultan terhadap kepuasan pelanggan pada Kantor Pelayanan Kekayaan Negara dan Lelang (KPKNL) Palu. 
2. Bukti fisik berpengaruh secara parsial terhadap kepuasan pelanggan pada Kantor Pelayanan Kekayaan Negara dan Lelang (KPKNL) Palu.

3. Kehandalan berpengaruh secara parsial terhadap kepuasan pelanggan pada Kantor Pelayanan Kekayaan Negara dan Lelang (KPKNL) Palu.

4. Daya tanggap berpengaruh secara parsial terhadap kepuasan pelanggan pada Kantor Pelayanan Kekayaan Negara dan Lelang (KPKNL) Palu.

5. Jaminan berpengaruh secara parsial terhadap kepuasan pelanggan pada Kantor Pelayanan Kekayaan Negara dan Lelang (KPKNL) Palu.

6. Empati berpengaruh secara parsial terhadap kepuasan pelanggan pada Kantor Pelayanan Kekayaan Negara dan Lelang (KPKNL) Palu.

\section{METODE PENELITIAN}

Penelitian ini menggunakan pendekatan kuantitatif dengan menggunakan sampel dari populasi yang digunakan. Populasi diartikan sebagai wilayah generalisasi yang terdiri atas obyek/subyek yang mempunyai kualitas dan karakteristik tertentu yang ditetapkan oleh peneliti untuk dipelajari dan kemudian ditarik kesimpulannya, (Sugiyono, 2014:115).

Penarikan sampel pada penelitian ini dengan melakukan sampling jenuh. Sampling jenuh adalah teknik penentuan sampel bila semua anggota populasi digunakan sebagai sampel. Istilah lain sampel jenuh adalah sensus (Sugiyono, 2014:122-123). Berdasarkan pendapat tersebut, maka sampel penelitian ini adalah seluruh pelanggan pada KPKNL Palu, dimana jumlah pelanggan pada Kantor Pelayanan Kekayaan Negara dan Lelang (KPKNL) Palu berjumlah 39 orang.

Tabel 1

Data Pelanggan KPKNL Palu selama Empat (4) Bulan Terakhir

\begin{tabular}{|c|c|c|}
\hline No & Bulan & Jumlah Pelanggan \\
\hline 1 & November & 9 \\
\hline 2 & Desember & 12 \\
\hline 3 & Januari & 10 \\
\hline 4 & Februari & 8 \\
\hline & Jumlah & 39 \\
\hline
\end{tabular}

Adapun analisis data yang digunakan dalam penelitian ini yaitu regresi linier berganda yang bertujuan untuk melihat pengaruh variabel independen terhadap variabel dependen. Regresi linier berganda adalah model regresi atau prediksi yang melibatkan lebih dari satu variabel bebas atau prediktor. Istilah regresi berganda dapat disebut juga dengan istilah multiple regression. Kata multiple berarti jamak atau lebih dari satu variabel.

Analisis regresi linier berganda adalah hubungan secara linear antara dua atau lebih variabel independen $(\mathrm{X} 1, \mathrm{X} 2, \ldots . \mathrm{Xn})$ dengan variabel dependen $(\mathrm{Y})$. Analisis ini untuk mengetahui arah hubungan antara variabel independen dengan variabel dependen apakah masing-masing variabel independen berhubungan positif atau negatif dan untuk memprediksi nilai dari variabel dependen apabila nilai variabel independen mengalami kenaikan atau penurunan.

Variabel dalam penelitian ini terdiri dari variabel independen $(\mathrm{X})$ dan variabel dependen $(\mathrm{Y})$. Adapun variabel independen dalam penelitian ini yaitu Kualitas Pelayanan (X) yang terdiri dari bukti fisik $\left(X_{1}\right)$, kehandalan $\left(X_{2}\right)$, daya tanggap $\left(X_{3}\right)$, jaminan $\left(X_{4}\right)$, dan empati $\left(X_{5}\right)$, sedangkan variabel dependen adalah Kepuasan pelanggan (Y). Adapun persamaan regresi linear berganda dalam penelitian ini, sebagai berikut: 
$\mathrm{Y}^{\prime}=\mathrm{a}+\mathrm{b} 1 \mathrm{X} 1+\mathrm{b} 2 \mathrm{X} 2+\ldots . .+\mathrm{bnXn}$

Keterangan:

$\mathrm{Y}=$ Variabel dependen (nilai yang diprediksikan)

$\mathrm{X}=$ Variabel independen

$\mathrm{a} \quad=$ Konstanta (nilai Y', apabila X1, X2 ....Xn $=0$ )

$\mathrm{b}=$ Koefisien regresi (nilai peningkatan ataupun penurunan)

\section{HASIL DAN PEMBAHASAN}

\section{Hasil Penelitian}

Hasil dari penelitian ini terdiri dari beberapa hasil pengujian, baik hasil regresi berganda maupun hasil pengujian hipotesis sebagaimana ditunjukkan berikut:

Tabel 2

Hasil Perhitungan Regresi Linear Berganda

\begin{tabular}{|c|c|c|c|c|c|}
\hline \multirow[t]{2}{*}{ Variabel } & \multicolumn{2}{|c|}{ Unstandardized Coefficients (B) } & \multirow{2}{*}{$\begin{array}{c}\begin{array}{c}\text { Standardized } \\
\text { Coefficients }\end{array} \\
\text { Beta } \\
\end{array}$} & \multirow[t]{2}{*}{$\mathbf{t}$} & \multirow[t]{2}{*}{ Sig. } \\
\hline & $\mathrm{B}$ & Std. Error & & & \\
\hline (Constant) & 1,618 & .738 & & 2.191 & .036 \\
\hline Bukti Fisik $\left(\mathrm{X}_{1}\right)$ & .093 & .152 & .123 & 608 & .547 \\
\hline Kehandalan $\left(\mathrm{X}_{2}\right)$ &.-143 & .165 &.-154 & -869 & .391 \\
\hline Daya Tanggap $\left(\mathrm{X}_{3}\right)$ & .127 & .176 & .112 & .721 & .476 \\
\hline Jaminan $\left(\mathrm{X}_{4}\right)$ & .301 & .142 & .314 & 2,124 & .041 \\
\hline Empati (X5) & .236 & .087 & .464 & 2,719 & .010 \\
\hline Multiple R & $=0,647$ & F-hitung & $=5,480$ & & \\
\hline R Square $\left(\mathrm{R}^{2}\right)$ & $=0,454$ & Sig. F & $=0,001$ & & \\
\hline
\end{tabular}

Sumber: Output For Windows Release 22.0, 2017

Berdasarkan uraian Tabel 2, maka persamaan regresi yang dibangun dengan menggunakan nilainilai yang diperlukan sebagai berikut:

$$
\mathrm{Y}=1,618+0,093 \mathrm{X} 1-0,143 \mathrm{X} 2+0,127 \mathrm{X} 3+0,301 \mathrm{X} 4+0,236 \mathrm{X} 5+\mathrm{e}
$$

\section{Pengujian Hipotesis}

\section{Pengujian Hipotesis Pertama Secara Simultan (Serempak/Uji F)}

Berdasarkan hasil uji regresi pada tabel di atas, diperoleh F-hitung sebesar 5.480 dengan tingkat signifikansi $0,000<0,05$, yang dapat diartikan bahwa variabel bukti fisik $\left(\mathrm{X}_{1}\right)$, kehandalan $\left(\mathrm{X}_{2}\right)$, daya tanggap $\left(\mathrm{X}_{3}\right)$, jaminan $\left(\mathrm{X}_{4}\right)$ dan empati $\left(\mathrm{X}_{5}\right)$ berpengaruh secara simultan terhadap kepuasan pelanggan (Y) pada Kantor Pelayanan Kekayaan Negara dan Lelang (KPKNL) Palu. Berdasarkan hasil tersebut dapat disimpulkan bahwa $\mathrm{H}_{0}$ ditolak dan $\mathrm{H}_{\mathrm{a}}$ diterima.

\section{Pengujian Hipotesis Kedua (Uji Parsial/Uji t)}

Uji t dilakukan dengan membandingkan nilai t signifikansi lebih kecil dari $\alpha 0,05$ maka dapat dipastikan bahwa variabel independen berpengaruh signifikan terhadap variabel dependen, sebaliknya jika nilai t signifikansi lebih besar dari $\alpha 0,05$ maka dapat dipastikan bahwa variabel independen berpengaruh tidak signifikan terhadap variabel dependen, dapat dijelaskan hasil uji t dari variabel independen adalah sebagai berikut:

1. Dimensi Bukti Fisik

Dimensi bukti fisik memiliki tingkat signifikansi t sig. $(0,547)>\alpha(0,05)$. Hal ini bermakna secara parsial dimensi bukti fisik berpengaruh tidak signifikan terhadap kepuasan pelanggan di Kantor 
Pelayanan Kekayaan Negara dan Lelang (KPKNL) Palu. Berdasarkan hasil di atas, maka untuk dimensi bukti fisik dalam penelitian yang telah dilakukan hal ini tidak terbukti $\left(\mathrm{H}_{0}\right.$ ditolak $\mathrm{H}_{\mathrm{a}}$ diterima). Artinya dimensi bukti fisik tidak memiliki pengaruh yang signifikan terhadap kepuasan pelanggan pada Kantor Pelayanan Kekayaan Negara dan Lelang (KPKNL) Palu.

2. Dimensi Kehandalan

Dimensi kehandalan memiliki tingkat signifikansi t sig. $(0,391)>\alpha(0,05)$. Hal ini bermakna secara parsial dimensi kehandalan berpengaruh tidak signifikan terhadap kepuasan pelanggan di Kantor Pelayanan Kekayaan Negara dan Lelang (KPKNL) Palu. Berdasarkan hasil di atas, maka untuk dimensi kehandalan dalam penelitian yang telah dilakukan hal ini tidak terbukti $\left(\mathrm{H}_{0}\right.$ ditolak $\mathrm{H}_{\mathrm{a}}$ diterima). Artinya dimensi kehandalan tidak memiliki pengaruh yang signifikan terhadap kepuasan pelanggan pada Kantor Pelayanan Kekayaan Negara dan Lelang (KPKNL) Palu.

3. Dimensi Daya Tanggap

Dimensi daya tanggap memiliki tingkat signifikansi t sig. $(0,476)>\alpha(0,05)$. Hal ini bermakna secara parsial dimensi daya tanggap berpengaruh tidak signifikan terhadap kepuasan pelanggan di

Kantor Pelayanan Kekayaan Negara dan Lelang (KPKNL) Palu. Berdasarkan hasil di atas, maka untuk dimensi daya tanggap dalam penelitian yang telah dilakukan hal ini tidak terbukti $\left(\mathrm{H}_{0}\right.$ ditolak $\mathrm{H}_{\mathrm{a}}$ diterima). Artinya dimensi daya tanggap tidak memiliki pengaruh yang signifikan terhadap kepuasan pelanggan pada Kantor Pelayanan Kekayaan Negara dan Lelang (KPKNL) Palu.

4. Dimensi Jaminan

Dimensi jaminan memiliki tingkat signifikansi t sig. $(0,041)<\alpha(0,05)$. Hal ini bermakna secara parsial dimensi jaminan berpengaruh signifikan terhadap kepuasan pelanggan pada Kantor

Pelayanan Kekayaan Negara dan Lelang (KPKNL) Palu. Berdasarkan hasil di atas, maka untuk dimensi jaminan dalam penelitian yang telah dilakukan hal ini terbukti ( $\mathrm{H}_{0}$ diterima $\mathrm{H}_{\mathrm{a}}$ ditolak). Artinya dimensi jaminan berpengaruh signifikan terhadap kepuasan pelanggan pada Kantor Pelayanan Kekayaan Negara dan Lelang (KPKNL) Palu.

5. Dimensi Empati

Dimensi empati memiliki tingkat signifikansi t sig. $(0,010)<\alpha(0,05)$. Hal ini bermakna secara parsial dimensi empati berpengaruh signifikan terhadap kepuasan pelanggan pada Kantor

Pelayanan Kekayaan Negara dan Lelang (KPKNL) Palu. Berdasarkan hasil di atas, maka untuk dimensi empati dalam penelitian yang telah dilakukan hal ini terbukti ( $\mathrm{H}_{0}$ diterima $\mathrm{H}_{\mathrm{a}}$ ditolak). Artinya dimensi empati berpengaruh signifikan terhadap kepuasan pelanggan pada Kantor Pelayanan Kekayaan Negara dan Lelang (KPKNL) Palu.

\section{Pembahasan}

\section{Bukti fisik, kehandalan, daya tanggap, jaminan dan empati berpengaruh terhadap kepuasan pelanggan}

Hasil penelitian yang telah dilakukan pada Kantor Pelayanan Kekayaan Negara dan Lelang (KPKNL) Palu diketahui hasil uji regresi diperoleh F-hitung sebesar 5.480 dengan tingkat signifikansi $0,000<0,05$, yang dapat diartikan bahwa dimensi bukti fisik $\left(\mathrm{X}_{1}\right)$, kehandalan $\left(\mathrm{X}_{2}\right)$, daya tanggap $\left(\mathrm{X}_{3}\right)$, jaminan $\left(\mathrm{X}_{4}\right)$ dan empati $\left(\mathrm{X}_{5}\right)$ berpengaruh signifikan secara simultan terhadap kepuasan pelanggan (Y) pada Kantor Pelayanan Kekayaan Negara dan Lelang (KPKNL) Palu. Hal ini mengambarkan bahwa Kantor Pelayanan Kekayaan Negara dan Lelang (KPKNL) Palu sudah menerapkan bukti fisik, kehandalan, daya tanggap, jaminan dan empati yang baik bagi para pelanggannya.

Berdasarkan hasil penelitian yang dilakukan menunjukan bahwa Kantor Pelayanan Kekayaan Negara dan Lelang (KPKNL) Palu harus bisa mempertahankan kelima dimensi bebas yaitu bukti fisik, kehandalan, daya tanggap, jaminan dan empati yang diberikan pada pelanggannya, karena kelima dimensi ini sudah berada pada interprestasi yang sangat baik atau sangat tinggi. Penelitian ini sesuai dengan penelitian yang dilakukan oleh (Januar Efendi Panjaitan et,al, 2016) yang menyatakan bahwa 
dari hasil uji F diperoleh F-hitung sebesar 3,966 dan angka signifikasi (P Value) sebesar 0,003<0,05. Atas dasar perbandigan tersebut, maka $\mathrm{H}_{1}$ diterima berarti dimensi kehandalan, jaminan, bukti fisik, empati, dan daya tanggap mempunyai pengaruh yang signifikan secara simultan (bersama-sama) terhadap dimensi kepuasan pelanggan.

\section{Bukti Fisik Berpengaruh Terhadap Kepuasan Pelanggan}

Tjiptono dalam Haryanto (2013) menyatakan bukti fisik (tangible) yaitu: kemampuan suatu perusahaan dalam menunjukkan eksistensinya kepada pihak eksternal. Penampilan dan kemampuan sarana dan prasarana fisik perusahaan. Seperti fasilitas (gedug, gudang, dan sebagainya). Menurut Lupiyoadi dan Hamdani (2006), karena suatu bentuk jasa tidak bisa dilihat, tidak bisa dicium, dan tidak bisa diraba maka aspek wujud fisik menjadi penting sebagai ukuran dari pelayanan. Pelanggan akan menggunakan indera pengelihatan untuk menilai suatu kualitas pelayanan. Pada saat yang bersamaan aspek ini juga merupakan salah satu sumber yang mempengaruhi harapan pelanggan. Karena dengan bukti fisik yang baik maka harapan konsumen menjadi lebih tinggi. Dalam penelitian ini yang menjadi bukti fisik adalah desain interior, eksterior dan penampilan pegawai. Sedangkan penelitian dalam sampel ini adalah pelanggan pada Kantor Pelayanan Kekayaan Negara dan Lelang (KPKNL) Palu.

Hasil dari uji hipotesis dalam penelitian ini menunjukkan bahwa bukti fisik (tangible) tidak berpengaruh signifikan terhadap kepuasan pelanggan pada Kantor Pelayanan Kekayaan Negara dan Lelang (KPKNL) Palu dan tidak sesuai dengan hipotesis yatu bukti fisik (tangible) berpengaruh terhadap kepuasan pelanggan. Dengan koefisien regresi 0,093 tidak terjadi pengaruh yang signifikan antara bukti fisik dan kepuasan pelanggan. Hal ini menunjukan bahwa meskipun nilai bukti fisik meningkat tidak akan memberikan pengaruh yang signifikan terhadap kepuasan pelanggan Pada Kantor Pelayanan Kekayaan Negara Lelang (KPNKL) Palu.

Hasil penelitian ini didukung dengan penelitian sebelumnya yang dilakukan oleh Rizqy et.al (2016), bahwa bukti fisik (tangible) tidak berpengaruh terhadap kepuasan pelanggan. Penelitan ini menunjukkan bahwa bukti fisik tidak selalu berpengaruh terhadap kepuasan pelanggan. Tidak adanya pengaruh yang signifikan dari bukti fisik (tangible) ini nampaknya dikarenakan pelanggan mempertimbangkan kondisi fisik ruangan untuk melakukan transaksi lelang saat berada di kantor Kantor Pelayanan Kekayaan Negara dan Lelang (KPKNL) Palu, terlepas dari belum memadainya ruangan kantor, sehingga dimungkinkan ada dimensi lain selain bukti fisik (tangible) yang mempengaruhi kepuasan pelanggan. Selain itu dari hasil analisis deskriptif terhadap temuan bahwa persepsi pelanggan terhadap kepuasan pelanggan cukup sehingga perlu untuk ditingkatkan. Dengan demikian $\mathrm{H}_{2}$ ditolak karena dimensi bukti fisik (tangible) tidak berpengaruh signifikan terhadap kepuasan pelanggan.

\section{Kehandalan Berpengaruh Terhadap Kepuasan Pelanggan}

Tjiptono dalam Haryanto (2013) menyatakan kehandalan (reliability) adalah kemampuan suatu perusahaan dalam memberikan pelayanan sesuai yang dijanjikan secara akurat dan terpercaya. Menurut Lupioayoadi dan Hamndani (2006), kinerja harus sesuai dengan harapan pelanggan yang berarti ketepatan waktu, pelayanan yang sama untuk semua pelanggan tanpa kesalahan, sikap yang simpatik, dan dengan akurasi yang tinggi.

Hasil uji hipotesis dalam penelitian ini menunjukkan bahwa kehandalan (reliability) berpengaruh negatif dan tidak signifikan terhadap kepuasan pelanggan Pada Kantor Pelayanan Kekayaan Negara dan Lelang (KPKNL) Palu. Dimensi ini terdiri dari beberapa indikator yaitu prosedur pelayanan (X2.1), proses transaksi (X2.2) dan proses pembayaran (X2.3).

Dimensi Kehandalan (reliability), yang terdiri dari prosedur pelayanan (X2.1) ini tidak memberikan pengaruh terhadap kepuasan pelanggan, terutama terhadap pelanggan yang berada di kota palu. Jadi dalam hal ini pelanggan memiliki persepsi bahwa prosedur pelayanan dalam melayani 
keluhan para pelanggan yang bertransaksi lelang tidak berpengaruh kepada pelanggan Kantor Pelayanan Kekayaan Negara dan Lelang (KPKNL) Palu.

Dimensi Kehandalan (reliability), yang terdiri dari proses transasksi (X2.2) ini tidak memberikan pengaruh terhadap kepuasan pelanggan, terutama terhadap pelanggan yang berada di kota palu. Jadi dalam hal ini pelanggan memiliki persepsi bahwa proses transaksi dalam melakukan transaksi lelang tidak berpengaruh kepada pelanggan Kantor Pelayanan Kekayaan Negara dan Lelang (KPKNL) Palu.

Dimensi Kehandalan (reliability), yang terdiri dari proses pembayaran (X2.3) ini tidak memberikan pengaruh terhadap kepuasan pelanggan, terutama terhadap pelanggan yang berada di kota palu. Jadi dalam hal ini pelanggan memiliki persepsi bahwa proses pembayaran dalam melakukan transaksi lelang tidak berpengaruh kepada pelanggan Kantor Pelayanan Kekayaan Negara dan Lelang (KPKNL) Palu.

Berdasarkan hasil yang didapatkan, maka di simpulkan bahwa dalam prosedur pelayanan, proses transaksi, dam proses pembayaran melalui Kehandalan (reliability) tidak mampu membangkitkan perasaan pelanggan terhadap kepuasan pelanggan Pada Kantor Pelayanan Kekayaan Negara dan Lelang (KPKNL) Palu. Dengan demikian $\mathrm{H}_{3}$ ditolak karena dimensi Kehandalan (reliability)) tidak berpengaruh signifikan terhadap kepuasan pelanggan.

\section{Daya Tanggap Berpengaruh Terhadap Kepuasan Pelanggan}

Tjiptono dalam Haryanto (2013) menyatakan daya tanggap (responsiveness) adalah kesediaan untuk membantu pelanggan dan memberikan pelayanan dengan segera dan tepat. Hasil dari uji hipotesis dalam penelitian ini menunjukkan bahwa data daya tanggap (responsiveness) tidak berpengaruh signifikan terhadap kepuasan pelanggan pada Kantor Pelayanan Kekayaan Negara dan Lelang (KPKNL) Palu. Hasil penelitian ini tidak sesuai dengan hipotesis penelitian yaitu daya tanggap (responsiveness) berpengaruh terhadap kepuasan pelanggan. Penelitian ini didukung oleh penelitian yang dilakukan oleh Rizqy et.al (2016), selain itu penelitian ini didukung oleh 5 gap atau kesenjangan dari Parasuraman et.al, yaitu gap antara spesifikasi kualitas jasa dan penyampaian jasa. Ada beberapa penyebab terjadinya gap, misalnya pegawai yang melayani kurang terlatih (belum menguasai tugasnya), masih kaku (kurang bersikap ramah dalam melayani pelanggan), beban kerja melampaui batas, tidak dapat memenuhi standar kinerja atau bahkan tidak mau memenuhi standar kinerja yang ditetapkan antara jasa yang dialami dengan persepsi jasa yang diharapkan. Ini adalah gap yang sering terjadi yaitu jasa yang diterima oleh pelanggan tidak sesuai dengan yang diharapkan oleh pelanggan. Dimana pelanggan mengharapkan sesuatu yang baik, namun ternyata yang diperoleh sangat mengecewakan.

Hasil dari penelitian menunjukkan bahwa kedua gap yang muncul ini erat kaitannya dengan pengalaman yang dirasakan oleh pelanggan, terutama pelanggan laki-laki. Dalam hal ini kecenderungan penyebab gap adalah standar kinerja yang diharapkan tidak terpenuhi oleh perusahaan. Hal ini dapat ditunjukkan dengan masih terlihatnya pelanggan yang bingung atas informasi yang diberikan oleh pihak perusahaan, hal ini tidak akan terjadi apabila pegawai KPKNL Palu dengan tanggap memberitahukan atau menyampaikan informasi sebelum terjadinya transaksi lelang. Dengan demikian $\mathrm{H}_{4}$ ditolak karena daya tanggap (responsiveness) tidak berpengaruh siginifikan terhadap kepuasan pelanggan.

\section{Jaminan Berpengaruh Terhadap Kepuasan Pelanggan}

Jaminan (assurance) adalah pengetahuan, keramahan, serta kemampuan pegawai untuk menumbuhkan kepercayaan pelanggan terhadap penyedia jasa (Tjiptono dalam Haryanto 2013) Hasil dari uji hipotesis dalam penelitan ini menunjukkan bahwa jaminan (assurance) berpengaruh positif dan signifikan terhadap kepuasan pelanggan pada Kantor Pelayanan Kekayaan Negara dan Lelang (KPKNL) Palu. Hasil penelitian ini sesuai dengan hipotesis yaitu jaminan (assurance) berpengaruh terhadap kepuasan pelanggan. Penelitian ini mendukung dari beberapa hasil penelitian-penelitian 
sebelumnya bahwa jaminan (assurance) berpengaruh terhadap kepuasan pelanggan yang dilakukan antara lain oleh: Sonya Mahanani (2010), Dwi Aryani dan Rosinta (2010), Felita Sasongko dan Dr.Hartono Subagio (2013).

Hasil penelitian ini menjelaskan bahwa jaminan (assurance) jasa pelayanan yang diberikan telah dilakukan sesuai dengan semestinya, artinya pegawai KPKNL Palu telah melakukan pelayanan dengan jaminan yang dapat dipertanggungjawabkan, diantaranya pihak perusahaan mampu menjaga kepercayaan dan mampu menigkatkan kinerja, dengan cara seperti ini maka proses transaksi lelang terjamin keamanannya. Selain itu dari penjabaran pada tabel 5.8 ditemukan beberapa temuan yaitu nilai kuisioner yang relatif tinggi dan adanya persepsi dari pelanggan yang bernilai tinggi sehingga perlu dipertahankan. Dengan demikian dapat disimpulkan $\mathrm{H}_{5}$ diterima karena dimensi jaminan (assurance) berpengatuh positif dan signifikan teradap kepuasan pelanggan.

\section{Empati Berpengaruh Terhadap Kepuasan Pelanggan}

Empati (emphaty) adalah perhatian secara individu yang diberikan oleh penyedia jasa sehingga pelanggan merasa penting, dihargai, dan dimengerti. (Tjiptono dalam Haryanto 2013). Menurut Lupiyoadi dan Hamdani (2006), empati (emphaty) yaitu perhatian dengan memberikan sikap tulus dan bersifat individual atau pribadi yang diberikan penyedia layanan jasa kepada pelanggan seperti kemampuan pegawai untuk berkomunikasi dengan pelanggan. Hasil dari uji hipotesis dalam penelitian ini menunjukkan bahwa empati (emphaty) berpengaruh positif dan signifikan terhadap kepuasan pelanggan. Penelitian ini mendukung dari beberapa hasil penelitian-penelitian sebelumnya bahwa empati (emphaty) berpengaruh terhadap kepuasan pelanggan, yang dilakukan antara lain oleh: Januar Efendi Panjaitan (2016), Dwi Aryani dan Rosinta (2010), Felita Sasongko dan Dr.Hartono Subagio (2013).

Hasil penelitian ini menjelaskan bahwa jaminan (emphaty) pegawai kepada pelanggan sudah mampu dilakukan, meskipun tidak semua pelanggan mendapatkan pelayanan dari dimensi empati (emphaty) ini. Hal ini bisa disebabkan karena pengalaman masing-masing pelanggan lelang. Dimana tidak setiap orang atau pelanggan dapat merasakan empati (emphaty) tersebut, kecuali para pelanggan lelang dengan waktu yang lama, sehingga lama-kelamaan pegawai KPKNL Palu hafal dengan pelanggan lelang karena seringnya bertatap muka. Selain itu dari hasil penjabaran hasil analisis deskriptif pada tabel 5.8 ditemukan adanya persepsi pelanggan tentang empati (emphaty) adalah baik sehingga perlu ditingkatkan. Dengan demikian dapat disimpulkan $\mathrm{H}_{6}$ diterima karena dimensi empati (emphaty) berpengaruh positif dan signifikan terhadap kepuasan pelanggan.

\section{KESIMPULAN DAN SARAN}

\section{Kesimpulan}

Berdasarkan dari hasil penelitian yang didapatkan, maka dapat ditarik beberapa kesimpulan berikut:

1. Bukti fisik, kehandalan, daya tanggap, jaminan dan empati secara silmultan berpengaruh positif terhadap kepuasan pelanggan pada Kantor Pelayanan Kekayaan Negara dan Lelang (KPKNL) Palu.

2. Bukti fisik berpengaruh positif dan tidak signifikan terhadap kepuasan pelanggan pada Kantor Pelayanan Kekayaan Negara dan Lelang (KPKNL) Palu.

3. Kehandalan berpengaruh negatif dan tidak signifikan terhadap kepuasan pelanggan pada Kantor Pelayanan Kekayaan Negara dan Lelang (KPKNL) Palu.

4. Daya tanggap berpengaruh positif dan tidak signifikan terhadap kepuasan pelanggan pada Kantor Pelayanan Kekayaan Negara dan Lelang (KPKNL) Palu.

5. Jaminan berpengaruh positif dan signifikan terhadap kepuasan pelanggan pada Kantor Pelayanan Kekayaan Negara dan Lelang (KPKNL) Palu. 
6. Empati berpengaruh positif dan signifikan terhadap kepuasan pelanggan pada Kantor Pelayanan Kekayaan Negara dan Lelang (KPKNL) Palu.

\section{Saran}

Berdasarkan hasil penelitian yang disimpulkan dan mengingat belum sempurnanya hasil penelitian ini, maka untuk penelitian selanjutnya dapat memperhatikan beberapa hal atau saran dari penelitian ini sebagai berikut:

1. Hasil dari penelitian ini disarankan dapat dijadikan sebagai sumber referensi dan informasi tambahan bagi peneliti, tentang kualitas pelayanan terhadap kepuasan pelanggan. Pada penelitian ini digunakan 5 dimensi kualitas pelayanan yang terdiri dari dimensi bukti fisik (tangible), kehandalan (reliability), daya tanggap (responsiveness), jaminan (assurance), empati (empathy), sebagai dimensi bebas. Sehingga pada peneliti selanjutnya dapat ditambahkan dimensi lain di luar 5 dimensi tersebut atau bahkan menggunakan dimensi kualitas pelayanan yang lain sebagai variabel bebas.

2. Untuk jaminan pada Kantor Pelayanan Kekayaan Negara Lelang (KPKNL) Palu, perlu upaya untuk mempertahankan dan meningkatkan kemampuan menjaga kepercayaan pelanggan dalam hal ini pegawai diharapkan lebih memberikan rasa aman dan terjamin terhadap pelanggan dalam melakukan transaksi lelang, pegawai harus selalu bersifat sopan, dan ramah, sehingga kurangnya keluhan dari pelanggan.

3. Untuk empati pada Kantor Pelayanan Kekayaan Negara Lelang (KPKNL) Palu, perlu upaya untuk mempertahankan dan meningkatkan perhatian kepada pelanggan, dalam hal ini pegawai diharapkan lebih memberikan perhatian khusus dalam memberikan pelayanan yang maksimal terhadap pelanggan.

\section{REFERENSI}

Aryani, Dwi dan Febrina Rosinta. (2010). Pengaruh Kualitas Layanan Terhadap Kepuasan Pelanggan Dalam Membentuk Loyalitas Pelanggan. Jurnal Ilmu Administrasi dan Organisasi, (2010), Vol.17, No.2.

Haryanto, Edy. (2013). Kualitas Layanan, Fasilitas dan Harga Pengaruhnya Terhadap Kepuasan Pengguna Jasa Layanan Pada Kantor Samsat Manado. Jurnal Emba, Vol.1, No. 3, Hal 750-760.

Panjaitan, Januar Efendi dan Ai Lili Yuiliati. (2016). Pengaruh Kualitas Pelayanan Terhadap Kepuasan Pelanggan Pada Jne Cabang Bandung. Jurnal Manajemen, Vol. 11, No. 2.

Kotler, Philip dan Keller, Kevin Lane. (2009). Manajemen Pemasaran, Edisi Ke Tiga Belas Jilid I \& II, Terjemahan Bob Sabran, MM. Jakarta: Erlangga.

Laksana, Fajar. (2008). Manajemen Pemasaran, Pendekatan Praktis. Edisi Pertama: Yogyakarta: Graha Ilmu.

Mahanani Sonya, (2010). Analisis Pengaruh Kualitas Pelayanan Terhadap Kepuasan Pelanggan Dalam Pembayaran Rekening Listrik (Studi Pada Unit Pelayanan Pelanggan Semarang Barat). Skripsi, Semarang: Universitas Diponegoro.

Rizqy, Warso, Fathoni. (2016). Pengaruh Kualitas Pelayanan Terhadap Kepuasan Konsumen (Studi Kasus Pada Konsumen Pt. Graha Service Indonesia Cabang Semarang). Journal of Management, Volume 2, No.2.

Syachrul. (2010). Analisis Tingkat Kepuasan Pelanggan Terhadap Pelayanan Mekanik Field PT Trakindo Utama Samarinda. Jurnal Eksis, Vol.6, No 2.

Sugiyono, (2014). “Metode Peneltian Bisnis”. Bandung: Penerbit Alfabeta.

Sunyoto, Danang. (2015). Penelitian Sumber Daya Manusia: Teori Kuesioner, Alat Statistik, dan

Contoh Riset. Jakarta: PT. Buku Seru. 
Suriani, N.N.

Sasongko, Felita dan Hartono Subagio. (2013). Pengaruh Kualitas Layanan Terhadap Kepuasan Pelanggan Restoran Ayam Penyet Ria. Jurnal Manajemen Pemasaran Petra, Vol. 1, No. 2, (2013) 1-7. 